\title{
HUBUNGAN ANTARA STATUS SOSIAL EKONOMI KELUARGA DENGAN STATUS GIZI ANAK USIA SEKOLAH
}

\section{The Correlation Between The Social Economic Of Family With The Nutritional of Children}

\author{
Ratna Kusuma Astuti ${ }^{1}$, Ganik Sakitri ${ }^{2}$ \\ Akademi Keperawatan Insan Husada Surakarta \\ (ratnakusuma@akperinsada.ac.id)
}

\begin{abstract}
ABSTRAK
Latar Belakang: Masalah kesehatan anak dan keadaan gizi anak di negara berkembang seperti Indonesia yang sebagian besar penduduknya berstatus social ekonomi rendah, merupakan masalah tersendiri yang memerlukan perhatian lebih dalam penanganannya. Keadaan gizi akan mempengaruhi pertumbuhan dan perkembangan anak. Pemenuhan gizi yang baik perlu diperhatikan mengingat anak adalah masyarakat masa depan yang menentukan tingkat kemajuan dan kesejahteraan suatu bangsa. Perubahan anak bias dinilai dengan variable pertumbuhan yaitu berat badan dan tinggi badan berdasarkan umur. Keadaan gizi ini berkaitan dengan ekonomi keluarga, keadaan sosial, lingkungan, perilaku kesehatan yang pada akhirnya akan berpengaruh terhadap pertumbuhannya. Tujuan Penelitian : Mengetahui hubungan Status Sosial Ekonomi Keluarga dengan Status Gizi Anak Usia Sekolah.

Metode : Jenis penelitian ini adalah cross sectional, dengan subyek penelitian siswa kelas 1 sampai kelas 5 SD N Godog 1 Polokarto, Sukoharjo. Teknik pengambilan sampel dengan proporsional stratified random sampling. Jumlah responden sebanyak 129 siswa. Data yang terkumpul di analisis dengan Chi Square $\left(\chi^{2}\right)$.

Hasil : Hasil uji korelasi dengan menggunakan Chi-Square $\left(\chi^{2}\right)$ diketahui bahwa nilai $\rho<0,05$ sehingga dapat dikatakan bahwa ada hubungan yang bermakna antara status social ekonomi keluarga dengan status gizi anak usia sekolah di SD N Godog 1 Polokarto, Sukoharjo. Ditinjau dari pendidikan ibu, pekerjaan ibu dan pendapatan keluarga.

Simpilan : Ada hubungan antara status social ekonomi keluarga dengan status gizi anak usia sekolah di SD N Godog 1 Polokarto, Sukoharjo.

Kata kunci : social ekonomi keluarga, status gizi anak.

\section{ABSTRACT}

Background:Problem of child health and nutritionalof children in developing countries like Indonesia are predominantly low social economic, is a separate issue that requires more attention to handling. The nutritional will affect the growth and development of children. Achievement of good nutrition should be considered given the childrens future is a society that determines the level of
\end{abstract}


progress and prosperity of a nation. Changes in children can be assessed by the growth variables weight and height by age. The nutritional is related to the family economy, social conditions, environment, health behaviors that will ultimately affect growth.

Purpose:This research was to determine the correlation between the social economic of family with the nutritional of children in elmentary school.

Method:The type of this research is cross sectional. The subject of this research were students in Grade 1 to Grade 5 elmentary school Godog 1 Polokarto, Sukoharjo. The technique of taking sample is using proportional stratified random sampling. The number of respondents as much as 129 students.

Result:The result of the correlation test using Chi-Square $\left(\chi^{2}\right)$ known that value $\rho$ $<0,05$ so we can say that there was a significant correlation between social economic of families with the nutritional of children in elmentary school Godog 1 Polokarto, Sukoharjo. Observed by maternal education, maternal employment and family income.

Conclusion: There is a significant corellation between social economic of families with nutritional of children in elementary school Godog 1 Polokarto, Sukoharjo.

Keywords: social economic of family, nutritional of children.

\section{PENDAHULUAN}

Status gizi merupakan gambaran keseimbangan antara kebutuhan tubuh akan zat gizi untuk pemeliharaan kehidupan, pertumbuhan, perkembangan, pemeliharaan fungsi normal tubuh dan untuk produksi energi dan intake zat gizi lainnya. Status gizi baik atau status gizi optimal terjadi bila tubuh memperoleh cukup zat-zat gizi yang digunakan secara efisien, sehingga memungkinkan pertumbuhan fisik, kemampuan kerja dan kesehatan secara umum pada tingkat setinggi mungkin (Almatsier, 2009).

Suhardjo (2003) menyatakanbahwaterdapat beberapa faktor yang dapat mempengaruhi status gizi diantaranya adalah faktor langsung: konsumsi makanan dan penyakit infeksi. Serta faktor tidak langsung antara lain: tingkat pendapatan, pengetahuan tentang gizi dan pendidikan. Sejalan dengan Suhardjo, Almatsier (2009) menyatakan bahwa berbagai faktor sosial ekonomi akan mempengaruhi pertumbuhan anak. Faktor sosial ekonomi tersebut antara lain: pendapatan keluarga, pekerjaan, pendidikan dan pemilikan kekayaan atau fasilitas.

Faktor sosial ekonomi keluarga akan turut menentukan hidangan yang disajikan untuk keluarga sehari-hari, baik kualitas maupun jumlah makanan. Hal ini dapat terlihat anak dengan sosial ekonomi tinggi tentunya pemenuhan kebutuhan gizi sangat cukup baik dibandingkan dengan anak dengan status sosial ekonomi rendah (Marimbi, 2010). Demikian juga dengan status pendidikan ibu, misalnya tingkat pendidikan rendah akan sulit untuk menerima arahan dalam pemenuhan gizi dan mereka sering tidak mau atau tidak meyakini pentingnya pemenuhan kebutuhan gizi atau pentingnya pelayanan kesehatan lain yang menunjang dalam membantu pertumbuhan dan perkembangan anak (Gerungan, 
2014). Pudjiadi (2011) memberikan gambaran bahwa semakin tinggi pendidikan ibu, menunjukkan semakin tingginya status sosial ekonomi keluarga tersebut.

Saat ini diperkirakan setengah rakyat Indonesia atau 100 juta mengalami kekurangan gizi, padahal disadari bahwa faktor gizi akan bisa menentukan kualitas bangsa (Karyadi, 2010). Menurut sumber data Dinas Kesehatan Provinsi Jawa Tengah dari 484.389 orang anak yang menderita gizi buruk adalah 15.500 atau sekitar 3,2\% dan gizi kurang sebesar 164.692 atau sekitar 34,7\% (Khomsan, 2016).

Dari hasil survey pendahuluan di SD N Godog 1 Polokarto, Sukoharjo didapat bahwa tingkat sosial ekonomi orang tua siswa di SD N Godog 1 Polokarto, Sukoharjo apabila ditinjau dari jenis pekerjaan sangat beragam, sebagian besar bekerja sebagai petani, pegawai dan wiraswasta. Demikian juga dengan status gizi anak usia sekolah di SD N Godog 1 Polokarto, Sukoharjo apabila dilihat melalui status gizi yang ditinjau dari penilaian antropometri WHO-NCHS lebih dari $40 \%$ siswa di SD N Godog 1 berstatus gizi normal.

Berdasarkan keanekaragaman tingkat sosial ekonomi keluarga dan pengamatan status gizi anak usia sekolah, maka akan timbul sebuah pertanyaan apakah ada hubungan antara status sosial ekonomi keluarga dengan status gizi anak usia sekolah di SD N Godog 1 Polokarto, Sukoharjo?

\section{METODOLOGI PENELITIAN}

Penelitian ini merupakan jenis penelitian observasional analitik dengan pendekatan cross sectional yaitu untuk mengukur variabel independen (status sosial ekonomi keluarga) dan variabel dependen (status gizi anak usia sekolah) secara bersamaan.Penelitian ini dilakukan selama 1 minggu pada tanggal 11-16 bulan April tahun 2018. Penelitian dilakukan di SD N Godog 1 Polokarto, Sukoharjo.

Populasi dalam penelitian ini siswa kelas 1 sampai kelas 5 SDN Godog 1 Polokarto, Sukoharjo yang berjumlah 166 siswa.Sampel dalam penelitian ini diambil dengan menggunakan teknik proporsional stratified random sampling. Pengambilan sampel ini dilakukan dengan cara acak pada beberapa kelompok atau anggota yang berstrata, yang memenuhi kriteria penelitian dimasukkan dalam peneitian atau keseluruhan populasi yang memenuhi kriteria inklusi dijadikan sampel penelitian.

Instrumen yang digunakan dalam penelitian ini ada dua macam yaitu metode kuesioner dan pengukuran antropometri. Metode kuesioner dalam penelitian ini untuk mengetahui status sosial ekonomi keluarga, sedangkan pengukuran antropometri dalam penelitian ini untuk mengumpulkan data status gizi anak.

Analisis data dalam penelitian ini menggunakan variabel sosial ekonomi keluarga berskala nominal, dan status gizi anak menggunakan skala nominal. Untuk mengetahui hubungan antar variabel digunakan uji Chi-Square. 


\section{HASIL DAN PEMBAHASAN}

\section{Analisis data}

Hasil kuisioner dan pengukuran berat badan dan tinggi badan 129 anak yang dijadikan sampel, diperoleh gambaran tentang kondisi status sosial ekonomi keluarga dan status gizi siswa yang bersekolah di SD N Godog 1 Polokarto, Sukoharjo.

a. Pendidikan Ibu

Tabel 1. DisribusiFrekuensi Pendidikan Ibu

\begin{tabular}{cccc}
\hline No & Pendidikan & Jumlah & \% \\
\hline 1 & Rendah & 38 & $29 \%$ \\
2 & Menengah & 71 & $55 \%$ \\
3 & Tinggi & 20 & $16 \%$ \\
& Jumlah & 129 & $100 \%$ \\
\hline
\end{tabular}

Tabel 1 diatas menunjukkan bahwa mayoritas ibu siswa SD $\mathrm{N}$ Godog 1 berpendidikan menengah, yaitu sebesar 55\%, sedangkan yang berpendidikan rendah sebesar $29 \%$ dan yang berpendidikan tinggi sebesar $16 \%$.

b. Pekerjaan Ibu

Tabel 2. DistribusiFrekuensiPekerjaan Ibu

\begin{tabular}{cccc}
\hline No & Pekerjaan & Jumlah & \% \\
\hline 1 & PNS & 7 & $5 \%$ \\
2 & Swasta & 14 & $11 \%$ \\
3 & Pedagang & 22 & $17 \%$ \\
4 & Petani & 23 & $18 \%$ \\
5 & Buruh & 18 & $14 \%$ \\
6 & Ibu RT & 45 & $35 \%$ \\
& Jumlah & 129 & $100 \%$ \\
\hline
\end{tabular}

Tabel 2 di atas mayoritas pekerjaan ibu siswa SD N Godog 1 adalah sebagai ibu rumah tangga yaitu sebesar $35 \%$, petani $18 \%$, pedagang $17 \%$, buruh $14 \%$, swasta $11 \%$, adapun pekerjaan ibu yang paling sedikit adalah sebagai PNS yaitu hanya sebesar $5 \%$.

c. Pendapatan Orang Tua

Tabel 3. DistribusiFrekuensiPenghasilanKeluarga

\begin{tabular}{cccc}
\hline No & Pendapatan Ayah & Jumlah & $\%$ \\
\hline 1 & $>$ UMR & 92 & $71 \%$ \\
2 & < UMR & 37 & $29 \%$ \\
\hline No & PendapatanIbu & Jumlah & $\%$ \\
\hline 1 & $>$ UMR & 92 & $71 \%$ \\
2 & $<$ UMR & 37 & $29 \%$ \\
\hline 3 & menunjukkan bahwa mayoritas ayah siswa SD N Godog 1
\end{tabular}

Tabel 3 menunjukkan bahwa mayoritas ayah siswa SD N Godog 1 berpendapatan lebih dari Rp1.513.000,00 per bulan, yaitu sebesar 71\%, sedangkan yang berpendapatan kurang dari Rp 1.513.000,00per bulan sebesar 29\%. Serta mayoritas ibu siswa SD N Godog 1 berpendapatan kurang dari Rp 1.513.000,00per bulan, yaitu sebesar 64\%, sedangkan yang berpendapatan lebih dari Rp 1.513.000,00per bulan sebesar 36\%. 


\section{Analisis Univariat}

Analisa univariat ini akan dibahas beberapa hal sebagai berikut:

a. Status Sosial Ekonomi

Kondisi sosial ekonomi keluarga yang diinterprestasikan menurut kriteria sosial ekonomi keluarga yang ditinjau dari beberapa aspek didapat seperti berikut:

Tabel 4. Status Sosial Ekonomi Keluarga

\begin{tabular}{cccc}
\hline No & Kriteria & F & \% \\
\hline 1 & Tinggi & 44 & $34 \%$ \\
2 & Sedang & 74 & $57 \%$ \\
3 & Rendah & 11 & $9 \%$ \\
& Jumlah & 129 & $100 \%$ \\
\hline
\end{tabular}

Hasil kuesioner diperoleh gambaran tentang status sosial ekonomi keluarga. Dari 129 responden didapat hasil bahwa mayoritas status sosial ekonomi keluarga siswa SD N Godog 1 berstatus sosial ekonomi menengah, yaitu sebesar 57\%. Kemudian kondisi status sosial ekonomi tinggi sebesar $34 \%$ dan yang berstatus sosial ekonomi rendah sebesar $9 \%$.

b. Status Gizi Anak

Hasil dari penimbangan berat badan dan pengukuran tinggi badan lalu diinterprestasikan menurut umur dan dimasukkan pada tabel WHONCHS, diperoleh hasil kurang dari persentil ke-5 kategori status gizi kurang, antara persentil ke-5 sampai dengan persentil ke-50 kategori status gizi normal dan lebih dari persentil ke-50 kategori status gizi lebih. Hasil pengukuran didapat:

Tabel 5. Status Gizi Anak Berdasarkan Berat Badan

\begin{tabular}{ccc}
\hline Kriteria & Jumlah & \% \\
\hline Gizi Lebih & 24 & $19 \%$ \\
Gizi normal & 74 & $57 \%$ \\
Gizi Kurang & 31 & $24 \%$ \\
Jumlah & 129 & $100 \%$ \\
\hline
\end{tabular}

Hasil penimbangan berat badan didapat bahwa kondisi gizi siswa SD $\mathrm{N}$ Godog 1 mayoritas berstatus gizi normal sebesar 57\%, berstatus gizi kurang sebesar 24\% dan siswa yang berstatus gizi lebih sebesar $19 \%$.

Tabel 6. Status Gizi Anak Berdasarkan Tinggi Badan

\begin{tabular}{ccc}
\hline Kriteria & Jumlah & $\%$ \\
\hline Gizi Lebih & 19 & $15 \%$ \\
Gizi normal & 72 & $56 \%$ \\
Gizi Kurang & 38 & $29 \%$ \\
Jumlah & 129 & $100 \%$ \\
\hline
\end{tabular}

Hasil pengukuran tinggi badan didapat bahwa kondisi gizi siswa SD $\mathrm{N}$ Godog 1 mayoritas berstatus gizi normal sebesar $56 \%$, berstatus gizi kurang sebesar $29 \%$ dan siswa yang berstatus gizi lebih sebesar $15 \%$. 


\section{Analisis Bivariat}

a. Tabulasi Silang Antara Pendidikan Ibu dengan Status Gizi Anak

Tabel 7. Crostab Pendidikan Ibu dengan Status Gizi Berdasarkan Berat Badan

\begin{tabular}{ccccc}
\hline \multirow{2}{*}{ Pendidikan } & \multicolumn{3}{c}{ Gizi } & \multirow{2}{*}{ Total } \\
\cline { 2 - 4 } & Kurang & Normal & Lebih & \\
\hline Rendah & 16 & 17 & 5 & 38 \\
Sedang & 12 & 42 & 17 & 71 \\
Tinggi & 3 & 14 & 3 & 20 \\
& 38 & 71 & 20 & 100 \\
\hline
\end{tabular}

Tabel7 diatas diketahui bahwa anak dengan status gizi kurang yang pendidikan ibu rendah16 siswa, pendidikan ibu menengah12 siswa dan pendidikan ibutinggi 3 siswa. Sedangkan anak dengan status gizi normal yang pendidikan ibu rendah 17 siswa, pendidikan ibu menengah 42 siswa dan pendidikan ibu tinggi14 siswa. Anak dengan status gizi lebih yang pendidikan ibu rendah5 siswa, pendidikan ibu menengah 17 siswa dan pendidikan ibu tinggi 3 siswa. Dari data tersebut diatas mayoritas siswa SD N Godog 1 adalah anak dengan status gizi normal dengan pendidikan ibu menengah.

Tabel 8. Crostab Pendidikan Ibu dengan Status Gizi Berdasarkan Tinggi Badan

\begin{tabular}{ccccc}
\hline \multirow{2}{*}{ Pendidikan } & \multicolumn{3}{c}{ Gizi } & \multirow{2}{*}{ Total } \\
\cline { 2 - 4 } & Kurang & Normal & Lebih & \\
\hline Rendah & 12 & 23 & 3 & 38 \\
Sedang & 25 & 39 & 7 & 71 \\
Tinggi & 1 & 10 & 9 & 20 \\
& 38 & 71 & 20 & 100 \\
\hline
\end{tabular}

Tabel8 diatas diketahui bahwa anak dengan status gizi kurang yang pendidikan ibu rendah 12 siswa, pendidikan ibu menengah 25 siswa dan pendidikan ibu tinggi 1 siswa. Sedangkan anak dengan status gizi normal yang pendidikan ibu rendah 23 siswa, pendidikan ibu menengah 39 siswa dan pendidikan ibu tinggi 10 siswa. Anak dengan status gizi lebih yang pendidikan iburendah 3 siswa, pendidikan ibu menengah 7 siswa dan pendidikan ibu tinggi 5 siswa. Dari data tersebut diatas mayoritas siswa SD N Godog 1 adalah anak dengan status gizi normal dengan pendidikan ibu menengah.

b. Tabulasi Silang Antara Pekerjaan Ibu dengan Status Gizi Anak

Tabel 9. Crostab Pekerjaan Ibu dengan Status Gizi Berdasarkan Berat Badan

\begin{tabular}{ccccc}
\hline \multirow{2}{*}{ Pekerjaan } & \multicolumn{3}{c}{ Gizi } & Total \\
\cline { 2 - 5 } & Kurang & Normal & Lebih \\
\hline PNS & 0 & 4 & 3 & 7 \\
Swasta & 0 & 7 & 7 & 14 \\
Pedagang & 2 & 16 & 4 & 22 \\
Petani & 6 & 13 & 4 & 23 \\
Buruh & 7 & 8 & 3 & 18 \\
Ibu RT & 16 & 25 & 4 & 45 \\
& 31 & 73 & 25 & 100 \\
\hline
\end{tabular}


Tabel 9 diatas diketahui bahwa anak berstatus gizi kurang yang ibu bekerja sebagai PNS dan swasta ada 0 siswa, pedagang 2 siswa, petani 6 siswa, buruh 7 siswa dan ibu rumah tangga 16 siswa. Anak dengan status gizi normal yang ibu bekerja sebagai PNS 4 siswa, swasta 7 siswa, pedagang 16 siswa, petani 13 siswa, buruh sebesar 8 siswa dan ibu rumah tangga 25 siswa. Sedangkan anak berstatus gizi lebih yang yang ibu bekerja sebagai PNS 3 siswa, swasta 7 siswa, pedagang 4 siswa, petani 4 siswa, buruh 3 siswa dan ibu rumah tangga 4 siswa. Dari data tersebut diatas mayoritas siswa SD N Godog 1 adalah anak dengan status gizi normal dengan ibu bekerja sebagai ibu rumah tangga.

Tabel 10. Crostab Pekerjaan Ibu dengan Status Gizi Berdasarkan Tinggi Badan

\begin{tabular}{ccccc}
\hline \multirow{2}{*}{ Pekerjaan } & \multicolumn{3}{c}{ Gizi } & \multirow{2}{*}{ Total } \\
\cline { 2 - 4 } & Kurang & Normal & Lebih & \\
\hline PNS & 1 & 3 & 3 & 7 \\
Swasta & 1 & 10 & 3 & 14 \\
Pedagang & 6 & 14 & 2 & 22 \\
Petani & 4 & 15 & 4 & 23 \\
Buruh & 10 & 8 & 0 & 18 \\
Ibu RT & 16 & 22 & 7 & 45 \\
& 38 & 72 & 19 & 100 \\
\hline
\end{tabular}

Tabel 10 diatas diketahui bahwa anak berstatus gizi kurang yang ibu bekerja sebagai PNS dan swasta 1 siswa, pedagang 6 siswa, petani 4 siswa, buruh 10 siswa dan ibu rumah tangga 16 siswa. Anak dengan status gizi normal yang ibu bekerja sebagai PNS 3 siswa, swasta 10 siswa, pedagang 14 siswa, petani 15 siswa, buruh 8 siswa dan ibu rumah tangga 22 siswa. Sedangkan anak berstatus gizi lebih yang yang ibu bekerja sebagai PNS 3 siswa, swasta 3 siswa, petani 4 siswa, buruh 0 siswa dan ibu rumah tangga 7 siswa. Dari data tersebut diatas mayoritas siswa SD N Godog 1 adalah anak dengan status gizi normal dengan ibu bekerja sebagai ibu rumah tangga.

c. Tabulasi Silang Antara Pendapatan Orang Tua dengan Status Gizi Anak Tabel 11. Crostab Pendapatan Orang Tua dengan Status Gizi Berdasarkan Berat Badan

\begin{tabular}{ccccc}
\hline \multirow{2}{*}{ Pendapatan } & \multicolumn{3}{c}{ Gizi } & \multirow{2}{*}{ Total } \\
\cline { 2 - 4 } & Kurang & Normal & Lebih & \\
\hline Rendah & 9 & 14 & 3 & 26 \\
Sedang & 16 & 45 & 7 & 68 \\
Tinggi & 6 & 14 & 15 & 35 \\
& 31 & 73 & 25 & 100 \\
\hline
\end{tabular}

Tabel11 diatas diketahui bahwa anak dengan status gizi kurang yang pendapatan orang tua rendah 9 siswa, pendapatan orang tua menengah 16 siswa dan pendapatan orang tua tinggi 6 siswa. Sedangkan anak dengan status gizi normal yang pendapatan orang tua rendah 14 siswa, pendapatan orang tua menengah 45 siswa dan pendapatan orang tua tinggi14 siswa. Anak dengan status gizi lebih yang pendapatan orang tua 
rendah 3 siswa, pendapatan orang tua menengah 7 siswa dan pendapatan orang tua tinggi 15 siswa. Dari data tersebut diatas mayoritas siswa SD N Godog 1 adalah anak dengan status gizi normal dengan pendapatan orang tua menengah.

Tabel 12. Crostab Pendapatan Orang Tua dengan Status Gizi Berdasarkan Tinggi Badan

\begin{tabular}{ccccc}
\hline \multirow{2}{*}{ Pendapatan } & \multicolumn{3}{c}{ Gizi } & \multirow{2}{*}{ Total } \\
\cline { 2 - 4 } & Kurang & Normal & Lebih & \\
\hline Rendah & 10 & 15 & 1 & 26 \\
Sedang & 22 & 39 & 7 & 68 \\
Tinggi & 6 & 18 & 11 & 35 \\
& 38 & 72 & 19 & 100 \\
\hline
\end{tabular}

Tabel12 diatas diketahui bahwa anak dengan status gizi kurang yang pendapatan orang tua rendah 10 siswa, pendapatan orang tua menengah 22 siswa dan pendapatan orang tua tinggi 6 siswa. Sedangkan anak dengan status gizi normal yang pendapatan orang tua rendah 15 siswa, pendapatan orang tua menengah 39 siswa dan pendapatan orang tua tinggi 18 siswa. Anak dengan status gizi lebih yang pendapatan orang tua rendah 1 siswa, pendapatan orang tua menengah 7 siswa dan pendapatan orang tua tinggi 11 siswa. Dari data tersebut diatas mayoritas siswa SD N Godog 1 adalah anak dengan status gizi normal dengan pendapatan orang tua menengah

d. Tabulasi Silang Antara Status Sosial dengan Status Gizi Anak

Tabel 13. Crostab Pendapatan Orang Tua dengan Status Gizi Berdasarkan Berat Badan

\begin{tabular}{ccccc}
\hline \multirow{2}{*}{ Sosial Ekonomi } & \multicolumn{3}{c}{ Gizi } & \multirow{2}{*}{ Total } \\
\cline { 2 - 4 } & Kurang & Normal & Lebih & \\
\hline Rendah & 4 & 5 & 2 & 11 \\
Sedang & 20 & 46 & 8 & 74 \\
Tinggi & 7 & 22 & 15 & 44 \\
& 31 & 73 & 25 & 100 \\
\hline
\end{tabular}

Tabel 13 diatas diketahui bahwa anak dengan status gizi kurang yang status sosial ekonomi keluarga rendah 4 siswa status sosial ekonomi keluarga menengah 20 siswa dan status sosial ekonomi keluarga tinggi 7 siswa. Sedangkan anak dengan status gizi normal yang status sosial ekonomi keluarga rendah 5 siswa, status sosial ekonomi keluarga menengah 46 siswa dan status sosial ekonomi keluarga tinggi 22 siswa. Anak dengan status gizi lebih yang status sosial ekonomi keluarga rendah 2 siswa, status sosial ekonomi keluarga menengah 8 siswa dan status sosial ekonomi keluarga tinggi 15 siswa. Dari data tersebut diatas mayoritas siswa SD N Godog 1 adalah anak dengan status gizi normal dengan status sosial ekonomi keluarga menengah. 
Avicenna Journal of Health Research. Vol 1 No 2. Oktober 2018 (13-26)

Tabel 14. Crostab Sosial Ekonomi Keluarga dengan Status Gizi Berdasarkan Tinggi Badan

\begin{tabular}{ccccc}
\hline \multirow{2}{*}{ Sosial Ekonomi } & \multicolumn{3}{c}{ Gizi } & \multirow{2}{*}{ Total } \\
\cline { 2 - 4 } & Kurang & Normal & Lebih & \\
\hline Rendah & 5 & 6 & 0 & 11 \\
Sedang & 26 & 43 & 5 & 74 \\
Tinggi & 7 & 23 & 14 & 44 \\
& 38 & 72 & 19 & 100 \\
\hline
\end{tabular}

Tabel14 diatas diketahui bahwa anak dengan status gizi kurang yang status sosial ekonomi keluarga rendah 5 siswa, status sosial ekonomi keluarga menengah 26 siswa dan status sosial ekonomi keluarga tinggi 7siswa. Sedangkan anak dengan status gizi normal yang status sosial ekonomi keluarga rendah 6 siswa, status sosial ekonomi keluarga menengah 43 siswa dan status sosial ekonomi keluarga tinggi 23 siswa. Anak dengan status gizi lebih yang status sosial ekonomi keluarga rendah 0 siswa, status sosial ekonomi keluarga menengah 5 siswa dan status sosial ekonomi keluarga tinggi 14 siswa. Dari data tersebut diatas mayoritas siswa SD N Godog 1 adalah anak dengan status gizi normal dengan status sosial ekonomi keluarga menengah.

e. Hasil Perhitungan Chi Square dan Koefisien Contigency.

Tabel 15. Chi Square dan Koefisien Contigency

\begin{tabular}{lcc}
\hline \multicolumn{1}{c}{ Hubungan } & $\left(\chi^{2}\right)$ & $\boldsymbol{C}$ \\
\hline Pendidikan Ibu dengan Gizi Anak (Berat Badan) & 10,728 & 0,277 \\
Pendidikan Ibu dengan Gizi Anak (Tinggi Badan) & 19,991 & 0,366 \\
Pekerjaan Ibu dengan Gizi Anak (Berat Badan) & 24,320 & 0,398 \\
Pekerjaan Ibu dengan Gizi Anak (Tinggi Badan) & 18,492 & 0,354 \\
$\begin{array}{l}\text { Penghasilan Orang Tua dengan Gizi Anak (Berat Badan) } \\
\text { Penghasilan Orang Tua dengan Gizi Anak (Tinggi }\end{array}$ & 18,427 & 0,354 \\
$\begin{array}{l}\text { Badan) } \\
\text { Sosial Ekonomi Keluarga dengan Gizi Anak (Berat } \\
\text { Badan) }\end{array}$ & 10,891 & 0,0297 \\
$\begin{array}{l}\text { Sosial Ekonomi Keluarga dengan Gizi Anak (Tinggi } \\
\text { Badan) }\end{array}$ & 18,217 & 0,352 \\
\hline
\end{tabular}

Hasil uji korelasidengan menggunakan Chi-Square $\left(\chi^{2}\right)$ diketahui bahwa semua nilai $\chi^{2}$ hitung ternyata lebih besar dari pada nilai $\chi_{\text {tabel }}^{2}$ (df:4) $=9,488$ dan $(\mathrm{df}: 10)=18,307$. Sehingga dapat dikatakan semua ada hubungan antara status sosial ekonomidengan status gizi anak usia sekolah.

Keadaan sosial ekonomi keluarga dapat ditinjau dari pendidikan keluarga, jenis pekerjaan keluarga, pendapatan keluarga dan pemilikan kekayaan atau fasilitas keluarga (Moehjie, 2003). Ditinjau dari tingkat pendidikan ibu, dari hasil analisa data yang diperoleh di SD $\mathrm{N}$ Godog 1 bahwa mayoritas ibu siswa mempunyai tingkat pendidikan menengah (SMP/SMA/Sederajat) yaitu sebesar $55 \%$, sehingga dapat dikatakan kemampuan ibu menerima informasi cukup baik. Pendidikan diperlukan untuk mendapatkan informasi, misalnya hal-hal yang menunjang kesehatan sehingga dapat meningkatkan kualitas hidup. Kemampuan menerima informasi ini akan mempengaruhi pengetahuan responden khususnya 
pengetahuan tentang kesehatan. Hal ini dapat berpengaruh pada pemilihan makanan bagi keluarga termasuk bagi anaknya. Menurut DepartemenGizi dan Kesehatan Masyarakat FKMUI bahwa pendidikan dapat mempengaruhi seseorang termasuk juga perilaku seseorang akan pola hidup terutama dalam memotivasi untuk sikap berperan serta dalam pembangunan kesehatan.

Ditinjau dari jenis pekerjaan, mayoritas pekerjaan ibu siswa SD N Godog 1 adalah sebagai ibu rumah tangga yaitu sebesar 35\%. Secara langsung pekerjaan tidak selalu berpengaruh terhadap tingkat pengetahuan yang dimiliki seseorang, namun interaksi seseorang yang berkerja dilingkungan yang didukung dengan akses informasi akan banyak pengetahuan dibandingkan dengan orang yang berkerja ditempat-tempat yang tertutup dari akses informasi, tidak hanya berkaitan dengan pekerjaan tersebut, mungkin bisa berhubungan dengan tema lain misalnya masalah kesehatan. Ketika individu dapat mengkomunikasikan masalah gizi, maka secara tidak disadari dapat meningkatkan pengetahuan individu tersebut. Hal ini sejalan dengan penelitian Gumala (2002), yang menyatakan bahwa interaksi individu selama berkerja dapat meningkatkan pengetahuan.

Ditinjau dari tingkat pendapatan orang tua mayoritas orang tua siswa SD N Godog 1 mempunyai pendapatan cukup yaitu sebesar 53\%. Secara langsung pendapatan keluarga sangat berpengaruh terhadap konsumsi makan sehari-hari. Menurut Suhardjo (2003) apabila pendapatan rendah maka makanan yang dikonsumsi tidak mempertimbangkan nilai gizi, akan tetapi nilai materi lebih menjadi pertimbangan. Namun demikian tidak menutup kemungkinan bahwa keluarga yang berpenghasilan rendah dapat mengkonsumsi makanan yang mempunyai nilai gizi baik.

Keadaan sosial ekonomi keluarga di SD N Godog 1 yang ditinjau dari pendidikan, pekerjaan, pendapatan dan kekayaan atau fasilitas dalam keluarga mayoritas keluarga siswa tergolong pada sosial ekonomi keluarga menengah yaitu sebesar 57\%. Secara langsung keadaan sosial ekonomi keluarga akan menentukan status gizi keluarga, khusunya dalam hal penyajian makanan. Akan tetapi, ekonomi keluarga yang baik tidak dengan sendirinya dapat diterjemahkan bertambah banyak uang yang dibelanjakan untuk makanan. Anggapan diatas diperkuat oleh Moejie (2003), menyatakan bahwa kelebihan penghasilan sering dibelanjakan untuk makanan yang tidak baik seperti: kopi, minuman karbonat, susu kental manis atau makanan yang kurang bergizi lainnya.

Keadaan gizi siswa SD N Godog 1 berdasarkan hasil penimbangan berat badan didapat bahwa kondisi gizi siswa mayoritas berstatus gizi normal yaitu sebesar 57\%, sama halnya dengan pengukuran tinggi badan didapat bahwa kondisi gizi siswa SD N Godog 1 mayoritas berstatus gizi normal sebesar 56\%. Angka tersebut diatas apabila diakumulasikan dengan data Dinas kesehatan Provinsi Jawa Tengah maka dapat ditarik kesimpulan bahwa status gizi anak usia sekolah di SD N Godog 1 adalah cukup baik. Menurut Almatsier (2009) terdapat berbagai faktor yang mempengaruhi status gizi pada anak antara lain kurangnya persediaan pangan dan kurang baiknya kualitas lingkungan. Adapun faktor lain yang mempengaruhi adalah kondisi sosial ekonomi dan budaya keluarga seperti pola asuh keluarga. Lebih dari sebagian siswa SD N Godog 1 mempunyai status 
gizi normal. Hal ini dapat disebabkan oleh beberapa faktor yang salah satu diantaranya adalah keadaan sosial ekonomi.

Hasil uji analisis bivariat apabila diuji korelasi dengan menggunakan ChiSquare $\left(\chi^{2}\right)$ didapatkan hasil sebagai berikut:

1. Tingkat Pendidikan Ibu dengan Status Gizi Anak

Hasil uji korelasi dengan menggunakan Chi-Square $\left(\chi^{2}\right)$ diketahui bahwa tingkat pendidikan ibu ternyata mempunyai pengaruh terhadap status gizi anak baik berdasarkan berat badan maupun tinggi badan.

Hal ini sejalan dengan teori Gerungan (2014) yang menyatakan bahwa semakin tinggi tingkat pendidikan seseorang, maka semakin mudah menerima informasi sehingga semakin banyak pula pengetahuan yang dimiliki. Sebaliknya tingkat pendidikan rendah akan sulit untuk menerima arahan dalam pemenuhan gizi dan mereka sering tidak mau atau tidak meyakini pentingnya pemenuhan kebutuhan gizi atau pentingnya pelayanan kesehatan lain yang menunjang dalam membantu pertumbuhan dan perkembangan anak. Hasil penelitian ini juga mendukung penelitian Latief (2010) yang membuktikan bahwa tingkat pendidikan ibu sangat berpengaruh terhadap perubahan sikap dan perilaku hidup sehat. Tingkat pendidikan ibu yang lebih tinggi akan memudahkan seseorang atau masyarakat untuk menyerap informasi dan menerapkan dalam perilaku dan gaya hidup sehari-hari, khususnya dalam hal kesehatan dan gizi.

2. Pekerjaan Ibu dengan Status Gizi Anak

Hasil uji korelasi dengan menggunakan Chi-Square $\left(\chi^{2}\right)$ diketahui bahwa tingkat pekerjaan ibu mempunyai pengaruh terhadap status gizi anak baik berdasarkan berat badan maupun tinggi badan. Dilihat dari hasil sebuah pekerjaan, pekerjaan merupakan suatu faktor yang berpengaruh terhadap gizi. Penelitian yang dilakukan oleh Yusrizal (2008), menyimpulkan bahwa faktor sosial ekonomi masyarakat (jenis pekerjaan) berpengaruh terhadap status gizi anak balita di wilayah Pesisir Kabupaten Bireuen.

3. Pendapatan Orang Tua dengan Status Gizi Anak

Hasil uji korelasi dengan menggunakan Chi-Square $\left(\chi^{2}\right)$ diketahui bahwa tingkat pendapatan orang tua mempunyai pengaruh terhadap status gizi anak baik berdasarkan berat badan maupun tinggi badan.

Yuliana (2013) menyatakan bahwa kemampuan keluarga untuk membeli bahan makanan antara lain tergantung pada besar kecilnya pendapatan keluarga. Keluarga dengan pendapatan terbatas kemungkinan besar akan kurang dapat memenuhi kebutuhan makanannya terutama untuk memenuhi kebutuhan zat gizi dalam tubuhnya.

4. Status Sosial Ekonomi Keluarga dengan Status Gizi Anak Usia Sekolah

Hasil uji korelasi dengan menggunakan Chi-Square $\left(\chi^{2}\right)$ diketahui bahwa ada hubungan antara status sosial ekonomi keluarga dengan status gizi anak usia sekolah di SD N Godog 1 Polokarto, Sukoharjo. Hal ini sejalan dengan pendapat Supriasa (2002), Peningkatan status gizi dalam masyarakat erat kaitannya dengan permasalahan status sosial ekonomi, dimana dalam hal ini memerlukan kebijakan yang menjamin setiap anggota masyarakat untuk memperoleh makanan yang cukup jumlah dan mutunya. Masalah gizi muncul 
akibat masalah ketahanan pangan ditingkat rumah tangga, yaitu kemampuan rumah tangga memperoleh makanan untuk semua anggota, sehingga masalah gizi tidak lagi semata-mata masalah kesehatan tetapi juga masalah kemiskinan, pemerataan dan masalah kesempatan kerja.

Hasil penelitian ini juga menguatkan hasil penelitian sebelumnya yang dilakukan oleh Latief (2010), menyimpulkan bahwa faktor sosial ekonomi merupakan salah satu faktor nyata yang mengakibatkan kekurangan gizi, bersama-sama dengan kondisi perumahan dan sanitasi lingkungan yang buruk, tidak tersedianya air bersih serta adanya penyakit infeksi. Karena semua ini dapat mempengaruhi penyediaan makanan sehari-hari termasuk menu dan jumlahnya bagi tiap-tiap keluarga.

\section{SIMPULAN DAN SARAN}

\section{Simpulan}

Hasil analisis dan pembahasan pada penelitian tentang hubungan antara status sosial ekonomi keluarga dengan status gizi anak usia sekolah di SD N Godog 1 Polokarto, Sukoharjo diperoleh simpulan sebagai berikut:

1. Hasil penimbangan berat badan dan pengukuran tinggi badan yang diinterprestasikan dengan umur dan diklasifikasikan dengan tabel WHONCHS, didapat bahwa kondisi gizi siswa SD N Godog 1 Polokarto, Sukoharjo mayoritas berstatus gizi normal.

2. Keadaan sosial ekonomi keluarga ditinjau dari:

a. Pendidikan Ibu

Hasil uji korelasi dengan menggunakan Chi-Square $\left(\chi^{2}\right)$, nilai $\chi^{2}$ hitung $>$ nilai $\chi^{2}$ tabel dan nilai $\rho<0,05$ maka Ho ditolak dan Ha diterima. Sehingga dapat dikatakan bahwa ada hubungan antara status sosial ekonomi keluarga ditinjau dari pendidikan ibu dengan status gizi anak usia sekolah di SD N Godog 1 Polokarto, Sukoharjo.

b. Pekerjaan Ibu

Hasil uji korelasi dengan menggunakan Chi-Square $\left(\chi^{2}\right)$, nilai $\chi^{2}$ hitung $>$ nilai $\chi^{2}$ tabel dan nilai $\rho<0,05$ maka Ho ditolak dan Ha diterima. Sehingga dapat dikatakan bahwa ada hubungan antara status sosial ekonomi keluarga ditinjau dari pekerjaan ibu dengan status gizi anak usia sekolah di SD N Godog 1 Polokarto, Sukoharjo.

c. Pendapatan Orang Tua

Hasil uji korelasi dengan menggunakan Chi-Square $\left(\chi^{2}\right)$, nilai $\chi^{2}$ hitung $>$ nilai $\chi^{2}$ tabel dan nilai $\rho<0,05$ maka Ho ditolak dan Ha diterima. Sehingga dapat dikatakan bahwa ada hubungan antara status sosial ekonomi keluarga ditinjau dari pendapatan orang tua dengan status gizi anak usia sekolah di SD N Godog 1 Polokarto, Sukoharjo.

3. Ada hubungan antara status sosial ekonomi keluarga dengan status gizi anak usia sekolah di SD N Godog 1 Polokarto, Sukoharjo. 


\section{Saran}

Hasil analisa dan pembahasan yang telah diuraikan, penulis memberikan beberapa saran yang bisa dijadikan untuk program selanjutnya. Diantaranya adalah:

1. Bagi Orang Tua

Orang tua hendaknya lebih memperhatikan masukan makanan bagi anak baik secara kualitas maupun kuantitas karena keadaan gizi dipengaruhi oleh konsumsi makan. Makanan yang bergizi tidak harus diperoleh dari makanan yang mahal. Oleh karena itu untuk orang tua yang mempunyai pendapatan keluarga rendah diharapkan dapat memanfaatkan hasil pekarangan dan peternakan sehingga anaknya bisa mempunyai status gizi yang baik. Selain itu orang tua harus rajin mencari informasi dengan mengikuti penyuluhanpenyuluhan tentang masalah gizi anak.

2. Bagi Pihak Sekolah

Salah satu upaya mengontrol kesehatan anak adalah dengan mengetahui status gizi anak, hal ini dapat dilakukan dengan penimbangan berat badan dan pengukuran tinggi badan secara rutin, oleh karena itu hendaknya dilakukan penimbangan berat badan dan pengukuran tinggi badan siswa di sekolah secara rutin agar diketahui apakah berat badan dan tinggi badan siswa tersebut lebih atau kurang.

3. Bagi Perawat

Salah satu peran perawat adalah sebagai pendidik. Oleh karena itu, perawat perlu memaksimalkan perannya sebagai pendidik dengan memberikan pendidikan kesehatan kepada para orang tua tentang pentingnya pemberian makanan yang tepat untuk membangun status gizi optimal sesuai dengan pertumbuhan dan perkembangannya serta memberikan contoh menu seimbang dari bahan makanan yang murah, tapi mengandung gizi yang cukup serta dapat menambah pengetahuan dan keterampilan sehingga dapat memberikan pelayanan yang optimal untuk masyarakat.

4. Bagi Penelitian Selanjutnya

a. Pengambilan data respondendengan membandingkan antara pedesaan dan perkotaan.

b. Pengambilan data dari orang tua siswa tidak hanya dengan pembagian kuesioner karena ada kemungkinan isian yang ditulis tidak sesuai dengan keadaan yang sebenarnya sehingga sebaiknya dengan wawancara langsung.

c. Dalam penilaian status gizi sebaiknya tidak hanya menggunakan antropometri tetapi dengan parameter lain, misalnya: biokimia (pemeriksaan laboratorium: protein, albumin serum) atau diet (jumlah berapa banyak porsi makan yang dikonsumsi dalam sehari dan jenis zat gizi yang dikonsumsi). 


\section{DAFTAR PUSTAKA}

Achadi. 2007. Gizi dan Kesehatan Masyarakat. Jakarta: PT. Raja Grafindo Persada.

Almatsier, Sunita. 2009. Prinsip Dasar Ilmu Gizi. Jakarta: PT. Gramedia Pustaka Utama.

Badan Pusat Statistik.2016. Upah Minimum Regional (UMR) Kabupaten Sukoharjo dalam angka 2009. Sukoharjo.

Biro Pusat Statistik. 2015. Statistik Sosial dan Kependudukan Jawa Tengah. Hasil Susenas. Jakarta: PS.

Chandra, Budiman. 2008. Metodologi Penelitian Kesehatan. Jakarta: Penerbit Buku Kedokteran EGC.

Departemen gizi dan kesehatan masyarakat FKM UI. 2007. Gizi dan Kesehatan Masyarakat. Jakarta: PT. Raja Grafindo Persada.

Gerungan, W.A. 2014. Psikologi Sosial. Bandung: PT. Refika Aditama.

Gumala, Ni Made Yuni. 2002. Perbedaan Tingkat Konsumsi Energi, Protein dan Status Gizi Balita Menurut Peran Ibu di Kabupaten Gianyar. Yogyakarta: Universitas Gajah Mada. Tesis.

Karyadi, Darwin. 2010. Visi Bangsa Sehat Melalui Sistem Kesehatan Nasional. http://www.tenagakesehatan.or.id.detail.php?id=15 Diakses tanggal 20 November 2017.

Khomsan, Ali. 2016. Sehat dengan Makanan Berkasiat. Jakarta: PT. Kompas Media Nusantara.

Latief, D. 2005. Penelitian Gizi di Desa Kebun Cau Kabupaten Tangerang. Bogor: IPB.

Marimbi, Hanum. 2010. Tumbuh Kembang, Status Gizi dan Imunisasi Dasar Pada Balita. Yogyakarta: Nuha Medika.

Moehjie. 2003. Ilmu Gizi. Jakarta: PT. Batara Akasara.

Pudjiadi, Solihin. 2011. Ilmu Gizi Klinis Pada Anak (Edisi Empat). Jakarta: FKUI. Suhardjo. 2003. Berbagai Cara Pendidikan Gizi. Jakarta: Bumi Aksara.

Supariasa, I.D.N. 2002. Penilaian Status Gizi. Jakarta: Buku Kedokteran EGC.

Yuliana. 2013. Kaitan Pertumbuhan Ekonomi, Kemiskinan dan Status Gizi. http://rudyct.tripod.com/sem2-03/yuliana.htmlDiakses tanggal 25 November 2017.

Yusrizal. 2008. Pengaruh Sosial Ekonomi dan Budaya Masyarakat Terhadap Status Gizi Anak Balita di Wilayah Pesisir Kabupaten Binuren. Medan: Unversitas Sumatra Utara. Tesis. 